\title{
Traditional Uighur Medicine Karapxa decoction, inhibits liver xanthine oxidase and reduces serum uric acid concentrations in hyperuricemic mice and scavenges free radicals in vitro
}

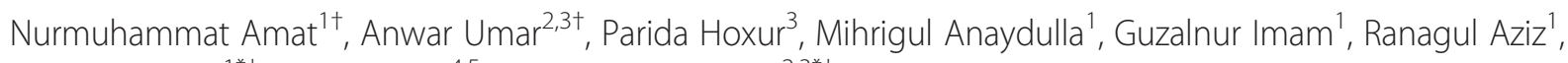
Halmurat Upur ${ }^{1 *+}$, Anake Kijjoa ${ }^{4,5}$ and Nicholas Moore ${ }^{2,3^{*}+}$

\begin{abstract}
Background: Karapxa decoction (KD) is a Traditional Uighur Medicine used for hepatitis, cholecystitis, gastralgia, oedema, gout and arthralgia. Because of its purported effect in gout, its effects were tested in hyperuricemic mice models induced by yeast extract paste or potassium oxonate, as well as its capacity to scavenge free radicals in vitro.

Methods: Hyperuricemia was induced in mice by yeast extract paste or potassium oxonate. KD was given orally for 14 days at 200, 400 and $800 \mathrm{mg} / \mathrm{kg} /$ day, with Allopurinol $10 \mathrm{mg} / \mathrm{kg} /$ day as positive control. Serum uric acid (UA), and liver xanthine oxidase activity $(\mathrm{XO})$ were measured. Scavenging activity of KD on 1, 1-diphenyl-2-picrylhydrazyl radicals (DPP•), nitric oxide $(\cdot \mathrm{NO})$, superoxide $\left(\mathrm{O}_{2} \cdot-\right)$, efficiency against lipid peroxidation, and $\mathrm{XO}$ inhibition were determined in vitro.

Results: KD inhibited liver $X O$ activity and reduced serum uric acid in hyperuricemic mice. KD also showed noticeable antioxidant activity, scavenging free radicals (DPP•, $\cdot \mathrm{NO}$ and $\mathrm{O}_{2} \cdot$ ). It was effective against lipid peroxidation and inhibited $\mathrm{XO}$ in vitro.
\end{abstract}

Conclusions: This study supports the traditional use of Karapxa decoction to treat hyperuricemia and gout.

Keywords: Karapxa decoction, Serum uric acid levels, Xanthine oxidase activities, Antioxidant, Potassium oxonate, Traditional Uyghur medicine

\section{Background}

Hyperuricemia and gout are metabolic disorders associated with abnormal amounts of uric acid in the body and uric acid crystals deposition or mobilisation in joints [1]. Hyperuricemia is considered a risk factor for gout, cardiovascular and many other diseases [2]. Uric acid, which is poorly soluble and deposits in articular and renal tissues, is the result of purine metabolism, [3] and

\footnotetext{
*Correspondence: halmurat@263.net; nicholas.moore@pharmaco.ubordeaux2.fr

${ }^{\dagger}$ Equal contributors

'Traditional Uighur Medicine Institute, Xinjiang Medical University, 393 Medical University Road, Urumqi, Xinjiang 830011, China

2Department of Pharmacology - Université de Bordeaux, F-33076 Bordeaux Cedex, France

Full list of author information is available at the end of the article
}

especially of xanthine by xanthine oxidase (XO). $\mathrm{XO}$ inhibitors such as allopurinol are available to block the final step in uric acid synthesis, reducing the production of uric acid [4]. Control of XO is a key factor in the prevention and treatment of uric acid-related diseases $[5,6]$. Gout is mostly manifest as painful swelling of digital joints, and can be quite incapacitating. Being both highly painful and visible, it is a prime target of traditional therapy. However gout is but the most visible aspect of uric acid excess: hyperuricemia and uric acid tissue deposition are associated with chronic inflammation, and increased risk of cardiovascular diseases, diabetes mellitus, decreased cognition in the elderly, among others. Decreasing uric acid production may therefore have further benefits than just relieving the painful symptoms of gout [7]. 
The Traditional Uighur Medicine (TUM) herbal formula, Karapxa decoction (KD), composed of seven herbal ingredients (Table 1), including seed, leaves or roots of celery, chicory, fennel and dodders, has long been used for gout and arthralgia in addition to other symptoms such as Hepatic coldness,adiposis hepatica, jaundice, hepatitis, cholecystitis, gastralgia [8]. KD is recorded in the State Pharmacopoeia of People's Republic of China in the Uighur Medicine volume. The seeds and roots of Cichorium glandulosum Boiss. et Huet (Chicory) serve as an important ingredient in KD. Previous studies have shown that extracts of Cichorium glandulosum Boiss. et Huet decrease serum uric acid and triglyceride concentrations in animal models [8-10], and may also decrease hyperuricemia in hypertriglyceridemia models [11]. Chicory is also commonly cited on websites for "natural" treatment of gout. Other components of KD also have effects, such as the hepatoprotective effect of Cuscuta chinensis against liver toxicity of acetaminophen and other drugs $[8,12,13]$. It is not clear however whether $K D$ can actually reduce serum uric acid levels in hyperuricemia models and inhibit $\mathrm{XO}$ activities. The aim of the present study was to evaluate the effects of KD in vivo on reduction of serum uric acid level and XO activity in hyperuricemic mice and to measure XO inhibition and free radical scavenging activity in vitro.

\section{Methods}

\section{Chemicals}

Xanthine and XO were purchased from Sigma (St. Louis, MO, USA). Potassium oxonate was purchased from Aldrich Inc. 2, 2-diphenyl-1-picrylhydrazyl (DPP•), sodium nitroprusside, N-(1-Naphthyl) ethylenediamine dihydrochloride, phenazine methosulfate (PMS), nitroblue tetrazolium (NBT), nicotinamide adenine dinucleotide (NADH), Ascorbic acid (AA) and thiobarbituric acid (TBA) were supplied by Sigma Co. (St Louis, USA). Assay kits for serum Uric Acid (UA) were obtained from Biosino Biotechnology Company Ltd. Assay kits for liver Xanthine oxidase (XO) were obtained from Nanjing Jiancheng Bioengineering Institute. All other chemicals were of analytical grade.

\section{Plant material}

$\mathrm{KD}$ is composed of air-dried powdered raw materials (Table 1) that were purchased from Xinjiang Autonomous Region Traditional Uighur Medicine Hospital (Urumqi, China) and authenticated by associate chief pharmacist Anwar Talip. The voucher specimens (NU-110108, NU100908, NU-110123, NU-110113, NU-110128, NU-100111) have been deposited in the Xinjiang Autonomous Region Traditional Uighur Medicine Hospital (Urumqi, China).

\section{Preparation of the aqueous extract of KD}

According to the recipe of $K D$ recommended by the State Pharmacopoeia of People's Republic of China, all herbs were cut into pieces, then $1 \mathrm{~kg}$ herbs were marinated in $10 \mathrm{~L}$ of warm distilled water for 12 hours. The aqueous extract was then prepared by boiling for $30 \mathrm{~min}$. The extract was filtered and concentrated under reduced pressure and temperature $\left(60^{\circ} \mathrm{C}\right)$ on a rotary evaporator, dried in vacuum conditions and stored in the refrigerator. The yield of the extract was found to be $21.84 \%$. The powder was suspended in $0.5 \%$ sodium carboxymethylcellulose (CMC-Na) solution before use.

\section{Animals}

Kunming mice weighing $18 \pm 22 \mathrm{~g}$ were obtained from the Experimental Animal Centre of Xinjiang Medical University. The mice were housed in plastic cages at room temperature of $22 \pm 1^{\circ} \mathrm{C}$ under a $12 \mathrm{~h}$ light-dark cycle, and provided with rodent chow and water ad libitum. All procedures were in strict accordance with the guidelines set of the Good Laboratory Practice centre at Xinjiang Autonomous Region Traditional Uighur Medicine Institute.

All experimental procedures used in the present study were approved by the Ethics Committee of the Xinjiang Medical University which has adopted the guidelines established by the Xinjiang Uighur Autonomous Region on Animal Care and Experimentation.

\section{Animal model of hyperuricemia in mice}

Two different in vivo hyperuricemia models were established using yeast-induced and potassium oxonate stimulated mice,

Table 1 Medicinal plants contained in Karapxa decoction

\begin{tabular}{|c|c|c|c|c|c|}
\hline Botanical name & Common name & Uighur name & Family & Part used & Quantities \\
\hline Apium graveolen L. & Celery & Karapxa uruki & Umbelliferae & Seed & $30 \mathrm{~g}$ \\
\hline Apium graveolen L. & Celery & Karapxa yiltizi & Umbelliferae & Root & $30 \mathrm{~g}$ \\
\hline Cuscuta chinensis Lam. & Dodders & Sirik yogay uruki & Convolvulaceae & Seed & $20 \mathrm{~g}$ \\
\hline Cichorium glandulosum Boiss. et Huet. & Chicory & Kasin uruki & Compositae & Seed & $15 \mathrm{~g}$ \\
\hline Foeniculum vulgare Mill & Fennel & Badranji buya yiltizi posti & Umbelliferae & Root & $30 \mathrm{~g}$ \\
\hline Cichorium glandulosum Boiss. et Huet. & Chicory & Kasin yiltizi & Compositae & Root & $15 \mathrm{~g}$ \\
\hline
\end{tabular}


with some modifications $[14,15]$. Yeast contains large amounts of purine and is used to induce hyperuricemia in mice. For yeast-induced hyperuricemic animal model experiments 60 mice were equally divided into 6 groups as shown in Table 2. The normal control group was given $0.5 \%$ CMC-Na orally for 14 days. All other groups of mice were given yeast extract paste $(30 \mathrm{~g} / \mathrm{kg})$ in $0.5 \% \mathrm{CMC}-\mathrm{Na}$, orally once per day for 14 days. Group 2 was the hyperuricemic animal model control. Groups 3, 4 and 5 were treated with $\mathrm{KD}(200 \mathrm{mg} / \mathrm{kg}, 400 \mathrm{mg} / \mathrm{kg}$ and $800 \mathrm{mg} / \mathrm{kg})$ by gavage for 14 days. Group 6 were treated with allopurinol $10 \mathrm{mg} / \mathrm{kg}$ orally for 14 days.

The uricase inhibitor potassium oxonate was used to induce hyperuricemia in mice [16]. Sixty mice were equally divided into 6 groups: the normal control was given orally only $0.5 \% \mathrm{CMC}-\mathrm{Na}$ for 14 days. All other mice were injected intraperitoneally with potassium oxonate $250 \mathrm{mg} /$ $\mathrm{kg} 1 \mathrm{~h}$ before drug administration. Group 2 served as hyperuricemic animal model control. Groups 3, 4 and 5 were treated with KD $(200 \mathrm{mg} / \mathrm{kg}, 400 \mathrm{mg} / \mathrm{kg}$ and $800 \mathrm{mg} / \mathrm{kg}$ ) for 14 days. Group 6 was treated with allopurinol $10 \mathrm{mg} / \mathrm{kg}$ orally for 14 days.

\section{Sample collection and measurement of serum UA, liver XO activities}

Whole blood samples were collected from mice $1 \mathrm{~h}$ after final administration by retro-orbital sinus puncture. The blood was allowed to clot for approximately $1 \mathrm{~h}$ at room temperature and then centrifuged at $3500 \times \mathrm{g}$ for $5 \mathrm{~min}$ to obtain the serum. The serum was stored at $-80^{\circ} \mathrm{C}$ until assayed. Mouse liver was excised, frozen immediately and stored at $-80^{\circ} \mathrm{C}$ until used. Tissue sample was homogenized in 5 vol. of $50 \mathrm{mM}$ ice-cold phosphate buffer $(\mathrm{pH}$ 7.5). The homogenate was then centrifuged for $10 \mathrm{~min}$ at $1500 \times \mathrm{g}$ at $4^{\circ} \mathrm{C}$. The lipid layer was carefully removed and the resulting fraction centrifuged further at $10,000 \times \mathrm{g}$ for $30 \mathrm{~min}$ and the supernatant was used for assays. Serum UA and liver XO was determined using a commercial kit (Nanjing Jiancheng Biochemical Reagent Co) according to the manufacturer's instructions. Liver $\mathrm{XO}$ activities were expressed as $\mathrm{nmol} / \mathrm{min}$ per $\mathrm{mg}$ protein. Protein concentration was determined using a commercial kit (Nanjing Jiancheng Biochemical Reagent Co) according to the manufacturer's instructions. The supernatant obtained after the last centrifugation was also used for the assays of $\mathrm{XO}$ activities.

\section{Assay of xanthine oxidase activity}

The XO activity was assayed spectrophotometrically under aerobic conditions as reported with minor modifications [17]. The assay mixture consisted of $1 \mathrm{ml}$ of test solution, $2.9 \mathrm{ml}$ of phosphate buffer ( $\mathrm{pH} 7.5)$, and $0.1 \mathrm{ml}$ of enzyme solution (0.01 units $/ \mathrm{ml}$ in phosphate buffer, $\mathrm{pH} 7.5)$, which was prepared immediately before use. After preincubation at $25^{\circ} \mathrm{C}$ for $15 \mathrm{~min}$, the reaction was initiated by the addition of $2 \mathrm{ml}$ of substrate solution $(50 \mathrm{mM}$ xanthine in the same buffer). The assay mixture was incubated at $25^{\circ} \mathrm{C}$ for $30 \mathrm{~min}$. The reaction was then stopped by adding of $1 \mathrm{ml}$ of $1 \mathrm{~N}$ hydrochloric acid and absorption was measured at $290 \mathrm{~nm}$ using a UV spectrophotometer. A blank was also prepared in the same way, but the enzyme solution was added to the assay mixture after adding $1 \mathrm{~N}$

Table 2 Effect of Karapxa decoction (KD) or Allopurinol (AP) on serum uric acid (UA) and liver xanthine oxidase (XO) activity in yeast extract paste (YEP) and potassium oxonate (PO) models of hyperuricemic mice in vivo

\begin{tabular}{|c|c|c|c|c|c|}
\hline Group & $\begin{array}{l}\text { Dose } \\
(\mathrm{mg} / \mathrm{kg})\end{array}$ & $\begin{array}{l}\text { UA } \\
(\mu \mathrm{mol} / \mathrm{L})\end{array}$ & $\begin{array}{l}\text { UA inhibition } \\
(\%)\end{array}$ & $\begin{array}{l}\text { Liver XO } \\
\text { (U/per mg protein) }\end{array}$ & $\begin{array}{l}\text { Liver XO inhibition } \\
(\%)\end{array}$ \\
\hline Normal & - & $6.12 \pm 2.12$ & - & $1.84 \pm 0.15$ & - \\
\hline Model (YEP) & - & $135.5 \pm 29.2^{\Delta}$ & - & $3.59 \pm 0.28^{\Delta}$ & - \\
\hline $\mathrm{YEP}+\mathrm{KD}$ & 200 & $96.7 \pm 27.8^{* *}$ & 28.6 & $3.05 \pm 0.21^{*}$ & 15.0 \\
\hline $\mathrm{YEP}+\mathrm{KD}$ & 400 & $81.8 \pm 22.9^{* *}$ & 39.6 & $2.65 \pm 0.13^{*}$ & 26.2 \\
\hline $\mathrm{YEP}+\mathrm{KD}$ & 800 & $65.5 \pm 15.9^{* *}$ & 51.6 & $2.15 \pm 0.22^{* *}$ & 40.1 \\
\hline$Y E P+A P$ & 10 & $15.0 \pm 3.0^{* *}$ & 88.9 & $1.28 \pm 0.25^{* *}$ & 64.3 \\
\hline Normal & - & $9.53 \pm 1.42$ & - & $1.62 \pm 0.23$ & - \\
\hline Model (PO) & - & $243.1 \pm 17.2^{\Delta}$ & - & $3.86 \pm 0.31^{\Delta}$ & - \\
\hline $\mathrm{PO}+\mathrm{KD}$ & 200 & $196.3 \pm 22.8^{* *}$ & 19.2 & $3.15 \pm 0.31$ & 18.4 \\
\hline $\mathrm{PO}+\mathrm{KD}$ & 400 & $162.5 \pm 21.0^{* *}$ & 33.2 & $2.81 \pm 0.13^{*}$ & 27.2 \\
\hline$P O+K D$ & 800 & $135.5 \pm 15.6^{* *}$ & 44.3 & $2.65 \pm 0.22^{*}$ & 31.4 \\
\hline $\mathrm{PO}+\mathrm{AP}$ & 10 & $25.0 \pm 19.0^{* *}$ & 89.7 & $1.48 \pm 0.15^{* *}$ & 61.7 \\
\hline
\end{tabular}

KD: Karapxa decoction; YEP, yeast extract paste model; AP, allopurinol, PO: potassium oxonate model. Data represent mean \pm S.E.M. of 10 animals.

${ }^{\Delta} \mathrm{P}<0.05$ compared to normal control group.

* $\mathrm{P}<0.05$ compared to model control group.

**P $<0.01$ compared to model control group. 
hydrochloric acid. The assay was done in triplicate. One unit of $\mathrm{XO}$ is defined as the amount of enzyme required to produce $1 \mu \mathrm{mol}$ of uric acid per min at $25^{\circ} \mathrm{C}$. Inhibition of the XO activity was measured spectrophotometrically at $290 \mathrm{~nm}$. The percentage of inhibition of XO activity (I\%) was calculated as \% $\mathrm{I}=(\mathrm{A}-\mathrm{B})-(\mathrm{C}-\mathrm{D}) /(\mathrm{A}-\mathrm{B}) \times 100$ where $\mathrm{A}$ is the $\mathrm{XO}$ activity without test extract (total uric acid); $\mathrm{B}$, the blank of $\mathrm{A}$ without $\mathrm{XO}$; $\mathrm{C}$, the enzyme activity with test extract (residual uric acid); and $\mathrm{D}$, the blank of $C$ without the enzyme.

\section{Antioxidant activity \\ Assay for DPP.-free radical scavenging activity}

DPP• is a stable free radical that accepts an electron or hydrogen radical to become a stable diamagnetic molecule. The model of scavenging the stable DPP• radical is widely used for relatively rapid evaluation of antioxidant activities. The free radical-scavenging activity of the extract was measured in terms of hydrogen donating or radical-scavenging ability using the stable DPP• radical. DPP•'s purple colour shows a characteristic absorption at $517 \mathrm{~nm}$. As antioxidants scavenge the free radical by hydrogen donation, the colour of the DPP• assay solution becomes light yellow resulting in a decrease in absorbance at $517 \mathrm{~nm}$. Assay was performed in a 96-well microplate using the previously described modified method. Different concentrations of test sample and ascorbic acid were prepared in ethanol and $100 \mu \mathrm{l}$ of the sample solution pipetted into each well and followed by $100 \mu \mathrm{l}$ of $0.1 \mathrm{mM}$ ethanolic DPP• solution. The reaction mixture was shaken vigorously and incubated at $37^{\circ} \mathrm{C}$ for $30 \mathrm{~min}$. Absorbance was measured at $517 \mathrm{~nm}$ using a microplate reader. The percentage inhibition (\%) of the DPP - radical by the samples was calculated using the following equation: \% inhibition $\left.=\left(A_{C}-A_{S}\right) / A_{C}\right) \times 100$, where $A_{C}$ is the absorbance of the control and $A_{S}$ is the absorbance of the sample. The concentration required to scavenge 50\% DPP• free radicals was calculated. All determinations were performed in triplicate.

\section{Nitric oxide $(\cdot \mathrm{NO})$ radical scavenging assay}

In the applied method, at physiological $\mathrm{pH}$ spontaneously generated nitric-oxide interacts with oxygen to produce nitrite ions that can be estimated using a Griess reagent. The scavenging activity of KD towards nitric-oxide was evaluated according to a previously described procedure [18]. The reaction mixture $(3 \mathrm{ml})$ containing sodium nitroprusside $(10 \mathrm{mM}, 2 \mathrm{ml}), 0.5 \mathrm{ml}$ phosphate buffer saline $(\mathrm{pH} 7.4,0.01 \mathrm{M})$ and extract or standard solution $(0.5 \mathrm{ml})$ was incubated at $25^{\circ} \mathrm{C}$ for $150 \mathrm{~min}$. Thereafter, $0.5 \mathrm{ml}$ of the reaction mixture containing nitrite was pipetted and mixed with $1 \mathrm{ml}$ of sulfanilic acid reagent $(0.33 \%$ sulfanilic acid in $20 \%$ glacial acetic acid) and allowed to stand for $5 \mathrm{~min}$ for completing diazotization.
Then, $1 \mathrm{ml}$ of naphthylethylenediamine dihydrochloride (0.1\%) was added, mixed and allowed to stand for $30 \mathrm{~min}$. The absorbance of pink coloured chromophore was measured at $540 \mathrm{~nm}$ against the corresponding blank solutions. The $\mathrm{IC}_{50}$ value is the concentration of sample required to inhibit $50 \%$ of nitric oxide free radical. All tests were carried out in triplicates.

\section{Assay for Superoxide anion $\left(\mathrm{O}_{2} \cdot\right)$ scavenging}

In the PMS-NADH-NBT system, superoxide anions are derived from dissolved oxygen by the PMS-NADH coupling reaction, which then reduced NBT to a blue coloured formazan. Absorbance is measured at $560 \mathrm{~nm}$. Decrease in absorbance is directly proportional to the antiradical potential of the product tested. Measurement of the superoxide anion scavenging activity of KD was based on the modified method previously reported [19]. Superoxide radicals were generated in phenazine methosulphate (PMS)-nicotinamide adenine dinucleotide (NADH) systems by $\mathrm{NADH}$ oxidation and assayed by nitroblue tetrazolium (NBT) reduction. In this experiment, the superoxide radicals were generated in $3 \mathrm{~mL}$ of Tris- $\mathrm{HCl}$ buffer $(16 \mathrm{mM}, \mathrm{pH}$ 8.0) containing $0.5 \mathrm{~mL}$ of NBT $(300 \mu \mathrm{M})$ solution, $0.5 \mathrm{~mL} \mathrm{NADH}(936 \mu \mathrm{M})$ solution, and $0.5 \mathrm{~mL}$ of $\mathrm{KD}$ solution at different doses. The reaction was started by adding $0.5 \mathrm{~mL}$ of PMS solution $(120 \mu \mathrm{M})$ to the mixtures. The reaction mixture was incubated at $25^{\circ} \mathrm{C}$ for $5 \mathrm{~min}$, and the absorbance at $560 \mathrm{~nm}$ measured against blank samples. All tests were performed in triplicate and results averaged. The percentage of inhibition was determined by comparing the results of control and test samples.

\section{Lipid peroxidation assay}

To test the in vitro inhibition of lipid peroxidation by the extracts, lipid peroxidation induced by $\mathrm{Fe}^{2+} /$ ascorbate system in mouse liver homogenate was used and thiobarbituric acid-reactive substances (TBARS) were measured with some modifications [20]. The reaction mixture contained mouse liver homogenate $0.1 \mathrm{ml}(25 \%, \mathrm{w} / \mathrm{v})$ in Tris- $\mathrm{HCl}$ buffer (20 mM, pH 7.0), $\mathrm{KCl}(150 \mathrm{mM}), \mathrm{FeSO}_{4} \cdot 6 \mathrm{H}_{2} \mathrm{O}$ $(0.8 \mathrm{mM})$, ascorbic acid $(0.3 \mathrm{mM})$ and various concentrations of the extract in a final volume of $0.5 \mathrm{ml}$ and was incubated for $1 \mathrm{~h}$ at $37^{\circ} \mathrm{C}$. The incubated reaction mixture $(0.4 \mathrm{ml})$ was treated with sodium dodecyl sulphate $(0.2 \mathrm{ml}, 8 \%)$ and thiobarbituric acid $(1.5 \mathrm{ml}, 20 \%)$. The total volume was then made up to $4 \mathrm{ml}$ by adding distilled water and kept in a water bath maintained at $100^{\circ} \mathrm{C}$ for $1 \mathrm{~h}$. After cooling, $1 \mathrm{ml}$ of distilled water and $5 \mathrm{ml}$ of n-butanol were added and shaken vigorously to separate the butanol fraction and measure TBARS formed at $535 \mathrm{~nm}$. The percentage of inhibition of lipid peroxide formation was determined by comparing the absorbance of the treated extract and non-treated samples. 


\section{Statistical analysis}

Values are presented as mean \pm S.E.M. Analysis of variance (ANOVA) was used to test for differences among treated and controlled groups. Inhibitory concentration $50 \%\left(\mathrm{IC}_{50}\right)$ of each sample was calculated by linear regression analysis using SPSS 11.0 software programme.

\section{Results}

\section{Effect on uric acid}

The effects of KD on yeast extract paste (YEP) and uricase inhibitor potassium oxonate (PO) induced hyperuricemia in mice are shown Table 2. YEP and PO caused hyperuricemia in mice, with serum uric acid level increased to $135.5 \pm 29.2 \mu \mathrm{mol} / \mathrm{L}$ and $243.1 \pm 37.2 \mu \mathrm{mol} / \mathrm{L}$, after 10 days oral YEP or $2 \mathrm{~h}$ after intraperitoneal PO, respectively. Fourteen days treatment with KD at 200, $400,800 \mathrm{mg} / \mathrm{kg}$ effectively opposed the increase of serum UA concentrations in both models. Allopurinol significantly lowered serum uric acid concentrations in experimental animals, to values not different from normal controls.

\section{Liver XO inhibitory activity}

The XO activities in normal groups were $1.84 \pm 0.35$ and $1.62 \pm 0.23 \mathrm{U} /$ per $\mathrm{mg}$ protein respectively. The liver $\mathrm{XO}$ activities were increased to $3.56 \pm 0.28$ and $3.86 \pm 0.31$ $\mathrm{U} /$ per mg protein in the model control mice $(\mathrm{p}<0.05)$. KD inhibited YEP-induced XO activity by $15.0 \%, 26.2 \%$, $40.1 \%$ in 200, 400 and $800 \mathrm{mg}$ XD-treated mice, respectively and PO-induced XO activity by $18.9 \%, 27.2 \%, 31.4 \%$ inhibition for 200, 400 and $800 \mathrm{mg} / \mathrm{kg}$ XD groups $(\mathrm{p}<$
0.05 except $200 \mathrm{mg}$, NS). Allopurinol inhibited mouse model XO by $64.3 \%$ and $61.66 \%$ at the dose of $10 \mathrm{mg} / \mathrm{kg}$ (both $\mathrm{p}<0.05$ ), obviously more than KD (Table 2).

\section{In vitro effects}

\section{Inhibition of xanthine oxidase}

At a concentration of $250 \mu \mathrm{g} / \mathrm{ml} \mathrm{KD}$, uric acid formation was completely suppressed; the $\mathrm{IC}_{50}$ value for $\mathrm{KD}$ inhibition was $25.8 \mu \mathrm{g} / \mathrm{ml}$. Allopurinol had an $\mathrm{IC}_{50}$ value of $6.28 \mu \mathrm{g} / \mathrm{ml}$ (Figure 1).

\section{DPP• radical scavenging}

The results concerning DPP• free radical scavenging effect of KD are indicated in Table 3. KD was a potent DPP• free radical scavenger. This activity was $31.1 \%$, $45.2 \%$, and $65.2 \%$, respectively, for 25,50 , and $100 \mu \mathrm{g} /$ $\mathrm{ml}$ of $\mathrm{KD}($ all $\mathrm{p}<0.05)$. The $\mathrm{IC}_{50}$ value was calculated to be $55.6 \mu \mathrm{g} / \mathrm{ml}$.

\section{Nitric oxide $(\bullet N O)$ radical scavenging}

The efficiency of $\mathrm{KD}$ to scavenge $\cdot \mathrm{NO}$ free radical is presented in Table 3. KD was found to possess strong NO scavenging ability, showing concentration-dependent activity $(\mathrm{p}<0.05)$. The $\mathrm{IC}_{50}$ value was $31.4 \mu \mathrm{g} / \mathrm{ml}$.

\section{Superoxide anion radical scavenging}

As shown in Table 3, KD exhibited significant and concentration dependent $\mathrm{O}_{2} \bullet$ - scavenging activity (5.8-83.5\% inhibition, $\mathrm{p}<0.05$ for concentrations above $6.25 \mu \mathrm{g} / \mathrm{ml}$ ) at $6.25-400 \mu \mathrm{g} / \mathrm{ml}$, The $\mathrm{IC}_{50}$ value was calculated to be $89.3 \mu \mathrm{g} / \mathrm{ml}$ for a scavenging effect at $49.7 \%$.

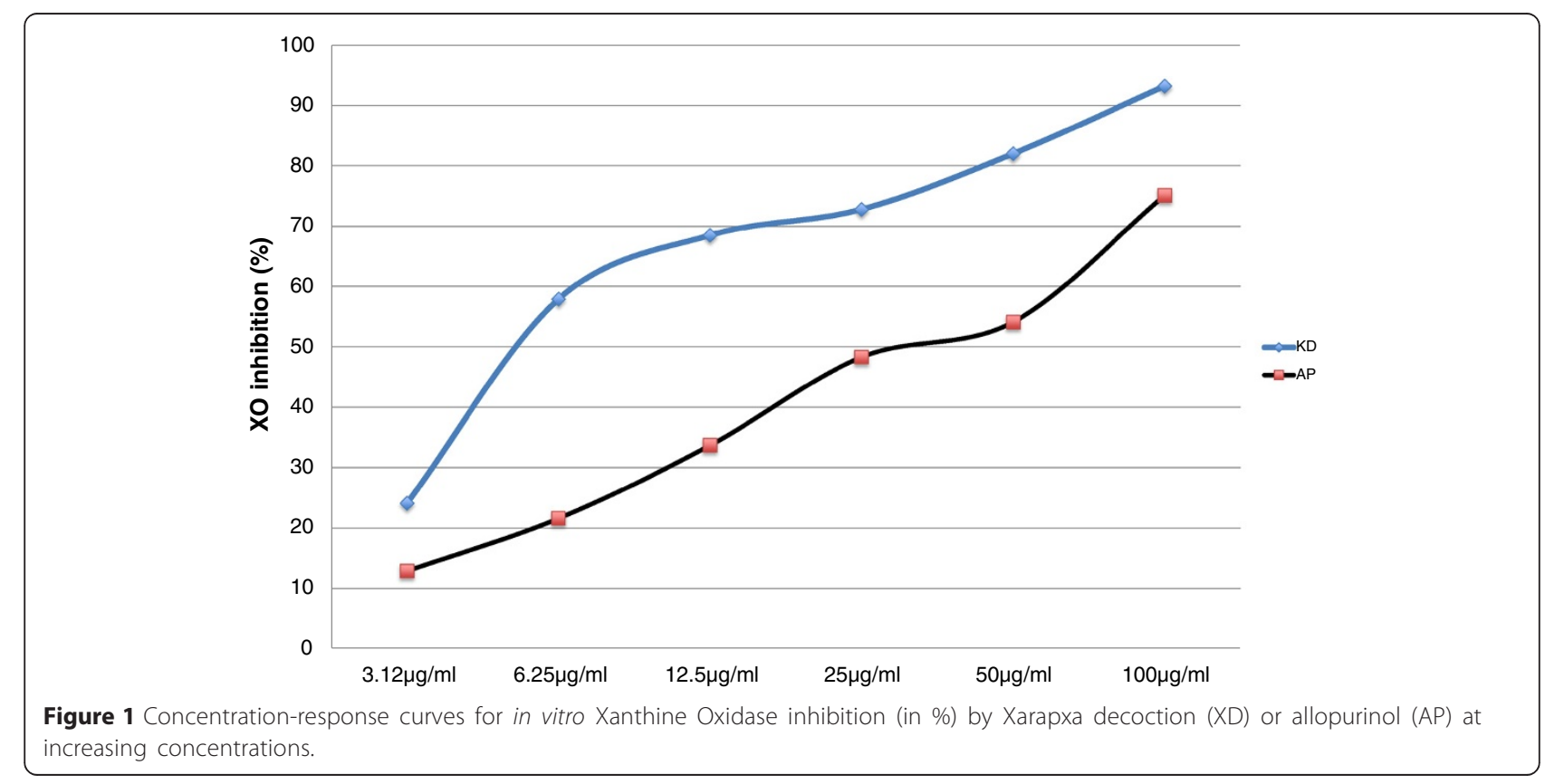


Table 3 Effect of increasing concentrations of Karapxa decoction (KD) on radical scavenging with DPP., Nitric oxide (•NO), Superoxide, and lipid peroxidation models, compared to ascorbic acid or butylated toluene controls

\begin{tabular}{|c|c|c|c|c|c|}
\hline Product & Concentration $(\mu \mathrm{g} / \mathrm{ml})$ & DPP. scavenging (\%) & •NO scavenging (\%) & Superoxide scavenging (\%) & Lipid peroxidation inhibition (\%) \\
\hline $\mathrm{KD}$ & $3.13 \mu \mathrm{g} / \mathrm{ml}$ & $6.13 \pm 1.23$ & $13.3 \pm 1.89$ & $4.8 \pm 0.4$ & $12.0 \pm 2.65$ \\
\hline$K D$ & $6.25 \mu \mathrm{g} / \mathrm{ml}$ & $15.7 \pm 1.46$ & $31.3 \pm 2.72$ & $8.6 \pm 4.23$ & $21.2 \pm 3.33$ \\
\hline $\mathrm{KD}$ & $12.50 \mu \mathrm{g} / \mathrm{ml}$ & $31.1 \pm 3.21$ & $49.1 \pm 2.84$ & $23.0 \pm 3.69$ & $29.3 \pm 2.15$ \\
\hline $\mathrm{KD}$ & $25.0 \mu \mathrm{g} / \mathrm{ml}$ & $45.2 \pm 2.56$ & $64.2 \pm 5.52$ & $33.4 \pm 4.12$ & $43.4 \pm 4.96$ \\
\hline $\mathrm{KD}$ & $50.0 \mu \mathrm{g} / \mathrm{ml}$ & $65.2 \pm 3.14$ & $71.5 \pm 4.82$ & $49.7 \pm 3.88$ & $48.5 \pm 4.48$ \\
\hline $\mathrm{KD}$ & $100.0 \mu \mathrm{g} / \mathrm{ml}$ & $82.2 \pm 3.67$ & $83.3 \pm 2.52$ & $69.1 \pm 5.19$ & $65.7 \pm 4.18$ \\
\hline $\mathrm{AA}$ & $50.0 \mu \mathrm{g} / \mathrm{ml}$ & $84.3 \pm 4.68$ & $39.2 \pm 3.39$ & & \\
\hline BHT & $50.0 \mu \mathrm{g} / \mathrm{ml}$ & & & $21.1 \pm 2.43$ & $61.1 \pm 2.91$ \\
\hline
\end{tabular}

KD: Karapka decoction; AA: Ascorbic acid; BHT: Butylated hydroxytoluene.

\section{Inhibition of lipid peroxidation}

KD displays dose-dependent lipid peroxidation inhibition, and this activity was $24.5 \%, 34.2 \%, 48.3 \%$, and $63.5 \%$, for $25 \mu \mathrm{g} / \mathrm{ml}, 50 \mu \mathrm{g} / \mathrm{ml}, 100 \mu \mathrm{g} / \mathrm{ml}$, and $200 \mu \mathrm{g} / \mathrm{ml} \mathrm{KD}$ (all p < $0.05)$. The concentration of KD needed for $50 \%$ inhibition was found to be $111.3 \mu \mathrm{g} / \mathrm{ml}$ (Table 3).

\section{Discussion}

Karapka decoction had dose-dependent effects on uric acid concentration and xanthine oxidase activity in two different hyperuricemic mice models. In addition, KD had free radical scavenging activities in vitro.

Gout and hyperuricemia are increasingly common disorders, reportedly afflicting more than 2 million men and women in the United States alone [21], and is progressing rapidly in China due probably to recent changes in dietary habits [22]. Gout and hyperuricemia are metabolic disorders associated with abnormal uric acid concentrations in the body, resulting in the deposition of urate crystals in the joints and kidneys that lead to inflammation, as well as gouty arthritis and uric acid nephrolithiasis. In addition to an increased risk of hyperuricemia and gout, excess uric acid is also related to cardiovascular disorders, nephrolithiasis, diabetes [7,23-32].

Two major mechanisms have been proposed for hyperucicemia in man, excess production and insufficient metabolisation of uric acid. Yeast extract paste and potassium oxonate were used to mimic both mechanisms: yeast represents excess production of UA, probably the main mechanism in man, and oxonate impairs metabolisation [15,23]. Yeast disturbs normal purine metabolism by increasing xanthine oxidase (XO) activity and generating large quantities of uric acid. This model is similar to human hyperuricemia, which is induced by high-protein diets. Another mouse hyperuricemia model was generated by a single intraperitoneal injection of potassium oxonate $250 \mathrm{mg} / \mathrm{kg}$. Potassium oxonate, a urate oxidase inhibitor, can raise the serum uric acid concentration by inhibiting the decomposition of uric acid by uricase, an enzyme that does not exist in man. Karapxa was found approximately equally effective in both models, but less than allopurinol.

Many bioactive products have been identified from the herbs in the $K D$ formula and pharmacological activity of those herbs has been reported. Celery seeds are used in arthritic pain relief, for treating rheumatic conditions and gout [33,34]. Essential oil, fatty acid, flavonoids isolated from Apium graveolen L., possesses antibacterial, antioxidative, hepaprotective, anti-tumor, and anti-cardiovascular disease abilities [35,36]. Certain indole-like compounds and indole alkaloids isolated from $A$. graveolens seeds were found to have antioxidant, cyclooxygenase and topoisomerase inhibitory activity [37]. The seeds of Cuscuta chinensis Lam. (Convolvulaceae), is a commonly used traditional Chinese herbal medicine used in improving and conditioning the liver and the kidney and also possesses anticancer effects, immunostimulant, antioxidant, and hepatoprotective activities [13,38-41].

The active constituents of $C$. chinensis include flavonol, flavonoids, lignans, quinic acid, and polysaccharide [42-45], which have been suggested to be responsible for the pharmacological activities observed from C. chinensis [46,47]. Cichorium glandulosum Boiss. et Huet is well known in Uighur medicine use for curing liver diseases, etc. In the Chinese Pharmacopoeia of the People's Republic of China, "Juju" (Herba Cichorii and Radix Cichorii) refers to the aerial parts and roots of Cichorium intybus L. and Cichorium glandulosum Boiss. et Huet. Different parts of these plants have been analysed, mostly for the presence of phenolics and sesquiterpene lactones. The major phenolics include flavonoids, coumarins and caffeic acid derivatives [48].

Many pharmacological studies on the same compounds have been performed earlier, finding anti-diabetic [49], antibacterial [50], hepatoprotective [12] and antioxidant effects. These constituents may be present at different amounts in the KD extracts and it is far from established which constituent(s) are responsible for the effects of the extracts. Further investigations are warranted to identify 
the active principle(s) of the extracts from $\mathrm{KD}$, responsible for the observed hypouricemic effects.

\section{Conclusion}

The objective of the present study was to test the hypouricemic and antioxidant effects of the KD, which is used in traditional Uighur medicine to treat gout and hyperuricemia. The results suggest that KD at the dosage of 200, 400 and $800 \mathrm{mg} / \mathrm{kg}$ has hypouricemic effects in both hyperuricemic mouse models. KD was also found to have inhibitory effects on mouse liver XO activity. Antioxidant activity was evident, through the ability to scavenge several free radicals $\left(\mathrm{DPPH}, \mathrm{NO}\right.$ and $\mathrm{O}_{2}$ ) and the effect on lipid peroxidation.

These results, though there is still a need for clinical validation, support the traditional use of KD to prevent or treat hyperuricemia and gout. It was less powerful than allopurinol, but may have the advantages of low cost and high acceptability in countries with limited resources or with a tradition of herbal medicinal treatment of diseases.

\author{
Abbreviations \\ KD: Karapxa Decoction; XO: Xanthine oxidase; DPPH: 1, 1-diphenyl-2-picrylhydrazyl \\ radicals; PMS: Phenazine methosulfate; NBT: Nitroblue tetrazolium; \\ $\mathrm{NADH}$ : Nicotinamide adenine dinucleotide; AA: Ascorbic acid; \\ TBA: Thiobarbituric acid; UA: Uric Acid; NO: Nitric oxide; $\mathrm{O}_{2}$ : Superoxide; \\ BHT: Butylated hydroxytoluene.
}

\section{Competing interests}

The authors declare that they have no competing interests.

\section{Authors' contributions}

NA, MA, Gl carried out most of the pharmacology studies, participated in the data analysis. and participated in its design and coordination and drafted the manuscript. $\mathrm{MH}$ helped with the preparation of samples. HU participated in the design of the study. RA, AK and NM participated in its design and coordination and drafted the manuscript. All authors read and approved the final manuscript.

\section{Acknowledgments}

We thank Xinjiang Uighur Autonomous Region Uighur Medicine Institute providing SPF Animal Lab and instrument during this research.

\begin{abstract}
Author details
${ }^{1}$ Traditional Uighur Medicine Institute, Xinjiang Medical University, 393 Medical University Road, Urumqi, Xinjiang 830011, China. ${ }^{2}$ Department of Pharmacology - Université de Bordeaux, F-33076 Bordeaux Cedex, France. ${ }^{3}$ Department of Pharmacology, Xinjiang Medical University, 830011-Urumqi, Xinjiang, People's Republic of China. ${ }^{4}$ Neurology Department, Xinjiang Medical University Affiliation of Traditional Chinese Medicine Hospital, 116 Huanghe Road, Urumqi, Xinjiang 83000, China. ${ }^{5}$ Instituto de Ciências Biomédicas de Abel Salazar (ICBAS), Universidade do Porto, Rua de Jorge Viterbo Ferreira 228, 40-50-313 Porto, Portugal.
\end{abstract}

Received: 4 August 2014 Accepted: 10 April 2015

Published online: 25 April 2015

\section{References}

1. Arromdee E, Michet CJ, Crowson CS, O'Fallon WM, Gabriel SE. Epidemiology of gout: is the incidence rising? J Rheumatol. 2002;29(11):2403-6.

2. Becker MA, Jolly M. Hyperuricemia and associated diseases. Rheum Dis Clin North Am. 2006;32(2):275-93. v-vi.

3. Unno T, Sugimoto A, Kakuda T. Xanthine oxidase inhibitors from the leaves of Lagerstroemia speciosa (L.) Pers. J Ethnopharmacol. 2004;93(2-3):391-5.
4. Sweeney AP, Wyllie SG, Shalliker RA, Markham JL. Xanthine oxidase inhibitory activity of selected Australian native plants. J Ethnopharmacol. 2001;75(2-3):273-7.

5. Liote F. Hyperuricemia and gout. Curr Rheumatol Rep. 2003;5(3):227-34.

6. Zhao X, Zhu JX, Mo SF, Pan Y, Kong LD. Effects of cassia oil on serum and hepatic uric acid levels in oxonate-induced mice and xanthine dehydrogenase and xanthine oxidase activities in mouse liver. J Ethnopharmacol. 2006;103(3):357-65.

7. Lin KC, Lin HY, Chou P. The interaction between uric acid level and other risk factors on the development of gout among asymptomatic hyperuricemic men in a prospective study. J Rheumatol. 2000;27:1501-5.

8. Upur H, Amat N, Blazekovic B, Talip A. Protective effect of Cichorium glandulosum root extract on carbon tetrachloride-induced and galactosamine-induced hepatotoxicity in mice. Food Chem Toxicol. 2009;47(8):2022-30.

9. Kong Y, Zhang B, Liu X, Sa Y, Ye G. Effect and mechanism study of Cichorii extracts on hyperuricemic model quail. Zhongguo Zhong Xi Yi Jie He Za Zhi. 2003;12:1139.

10. Ding L, Liu JL, Hassan W, Wang LL, Yan FR, Shang J. Lipid modulatory activities of Cichorium glandulosum Boiss et Huet are mediated by multiple components within hepatocytes. Sci Rep. 2014;4:4715.

11. Li H, Liu X, Zhang B, Ni L, Ling Z. Effects of active component in Cichorii on lipid metabolism of rat with hypertriglyceridemia complicated by hyperuricemia and hyperglycemia. Zhong Xi Yi Jie He Xue Bao. 2008;6:157-62.

12. Ahmed B, Al-Howiriny TA, Siddiqui AB. Antihepatotoxic activity of seeds of Cichorium intybus. J Ethnopharmacol. 2003;87(2-3):237-40.

13. Yen FL, Wu TH, Lin LT, Lin CC. Hepatoprotective and antioxidant effects of Cuscuta chinensis against acetaminophen-induced hepatotoxicity in rats. J Ethnopharmacol. 2007;111(1):123-8.

14. Chen L, Hsieh MS, Ho HC, Liu YH, Chou DT, Tsai SH. Stimulation of inducible nitric oxide synthase by monosodium urate crystals in macrophages and expression of iNOS in gouty arthritis. Nitric Oxide. 2004;11(3):228-36.

15. Hall $I H$, Scoville JP, Reynolds DJ, Simlot R, Duncan P. Substituted cyclic imides as potential anti-gout agents. Life Sci. 1990;46(26):1923-7.

16. Wang Y, Zhu JX, Kong LD, Yang C, Cheng CH, Zhang X. Administration of procyanidins from grape seeds reduces serum uric acid levels and decreases hepatic xanthine dehydrogenase/oxidase activities in oxonate-treated mice. Basic Clin Pharmacol Toxicol. 2004;94(5):232-7.

17. Delporte C, Backhouse N, Erazo S, Negrete R, Vidal P, Silva X, et al. Analgesic-antiinflammatory properties of Proustia pyrifolia. J Ethnopharmacol. 2005;99(1):119-24.

18. Marcocci L, Packer L, Droy-Lefaix MT, Sekaki A, Gardes-Albert M. Antioxidant action of Ginko biloba extract Egb 761. Methods Enzymol. 1994;234:462-76.

19. Robak J, Gryglewski RJ. Flavonoids are scavengers of superoxide anions. Biochem Pharmacol. 1988;37(5):837-41.

20. Ohkawa H, Ohishi N, Yagi K. Assay for lipid peroxides in animal tissues by thiobarbituric acid reaction. Anal Biochem. 1979;95(2):351-8.

21. Kramer HM, Curhan G. The association between gout and nephrolithiasis: the national health and nutrition examination survey III, 1988-1994. Am J Kidney Dis. 2002;40:37-42.

22. Li Y, Stamler J, Xiao Z, Folsom A, Tao S, Zhang H. Serum uric acid and its correlates in Chinese adult populations, urban and rural, of Beijing. The PRC-USA collaborative study in cardiovascular and cardiopulmonary epidemiology. Int J Epidemiol. 1997;26(2):288-96.

23. Chen GL, Wei W, Xu SY. Effect and mechanism of total saponin of Dioscorea on animal experimental hyperuricemia. Am J Chin Med. 2006;34(1):77-85.

24. Chen SY, Chen CL, Shen ML, Kamatani N. Clinical features of familial gout and effects of probable genetic association between gout and its related disorders. Metabol. 2001;50:1203-7.

25. Nakanishi N, Suzuki K, Kawashimo H, Nakamura K, Tatara K. Serum uric acid: correlation with biological, clinical and behavioralfactors in Japanese men. J Epidemiol. 1999;9:99-106

26. Barber DA, Harris SR. Oxygen free radicals and antioxidants: a review. American pharmacy. 1994;NS34(9):26-35.

27. George J, Struthers AD. The role of urate and xanthine oxidase inhibitors in cardiovascular disease. Cardiovasc Ther. 2008;26(1):59-64.

28. Gutteridge JM. Thiobarbituric acid-reactivity following iron-dependent freeradical damage to amino acids and carbohydrates. FEBS Lett. 1981;128(2):343-6. 
29. Holley $\mathrm{AE}$, Cheeseman $\mathrm{KH}$. Measuring free radical reactions in vivo. Br Med Bull. 1993:49(3):494-505.

30. Khosla UM, Zharikov S, Finch JL, Nakagawa T, Roncal C, Mu W, et al. Hyperuricemia induces endothelial dysfunction. Kidney Int. 2005;67(5):1739-42.

31. Martin-Gallan P, Carrascosa A, Gussinye M, Dominguez C. Estimation of lipoperoxidative damage and antioxidant status in diabetic children: relationship with individual antioxidants. Free Radic Res. 2005;39(9):933-42.

32. Nishikimi M, Rao NA, Yagi K. Occurrence of superoxide anion in the reaction of reduced phenazine methosulphate and molecular oxygen. Biochem Biophys Res Commun. 1972:46:849-54.

33. Bjeldanes LF, Kim IS. Phthalide components of celery essential oil. J Org Chem. 1997;42:2333-5.

34. Satyavati GV, Raina MK. Medicinal plants of India, vol. 1. New Delhi, India: Pub. Indian Council of Medical Research; 1976. p. 80-107.

35. Gao SM, Yang J, Li WY. Analysis on the chemical ingredients and their pharmacological effect in celery. J Anhui Agric Sci. 2008;36:1474-5.

36. Singh A, Handa SS. Hepatoprotective activity of Apium graveolens and Hygrophila auriculata against paracetamol and thioacetamide intoxication in rats. J Ethnopharmacol. 1995;49(3):119-26.

37. Momin RA, Nair MG. Antioxidant, cyclooxygenase and topoisomerase inhibitory compounds from Apium graveolens Linn. seeds. Phytomedicine. 2002;9(4):312-8.

38. Bao X, Wang Z, Fang J, Li X. Structural features of an immunostimulating and antioxidant acidic polysaccharide from the seeds of Cuscuta chinensis. Planta Med. 2002;68(3):237-43.

39. Nisa M, Akbar S, Tariq M, Hussain Z. Effect of Cuscuta chinensis water extract on 7,12-dimethylbenz[a]anthracene-induced skin papillomas and carcinomas in mice. J Ethnopharmacol. 1986;18(1):21-31.

40. Umehara K, Nemoto K, Ohkubo T, Miyase T, Degawa M, Noguchi H. Isolation of a new 15-membered macrocyclic glycolipid lactone, Cuscutic Resinoside a from the seeds of Cuscuta chinensis: a stimulator of breast cancer cell proliferation. Planta Med. 2004;70(4):299-304.

41. Zheng HZ, Dong ZH, She J. Modern study of traditional Chinese medicine 1st ed. Beijing: Beijing Xue Yuan Press of the People's Repubic of China; 1998.

42. Du XM, Kohinata K, Kawasaki T, Guo YT, Miyahara K. Components of the ether-insoluble resin glycoside-like fraction from Cuscuta chinensis. Phytochemistry. 1998;48(5):843-50.

43. Wang Z, Fang JN, Ge DL, Li XY. Chemical characterization and immunological activities of an acidic polysaccharide isolated from the seeds of Cuscuta chinensis Lam. Acta Pharmacol Sin. 2000;21(12):1136-40.

44. Ye M, Li Y, Yan Y, Liu H, Ji X. Determination of flavonoids in Semen Cuscutae by RP-HPLC. J Pharm Biomed Anal. 2002;28(3-4):621-8.

45. Ye M, Yan Y, Guo DA. Characterization of phenolic compounds in the Chinese herbal drug Tu-Si-Zi by liquid chromatography coupled to electrospray ionization mass spectrometry. Rapid Commun Mass Spectrom. 2005;19(11):1469-84.

46. Cornwell T, Cohick W, Raskin I. Dietary phytoestrogens and health. Phytochemistry. 2004;65(8):995-1016.

47. Williamson G, Barron D, Shimoi K, Terao J. In vitro biological properties of flavonoid conjugates found in vivo. Free Radic Res. 2005;39(5):457-69.

48. Malarz J, Stojakowska A, Szneler E, Kisiel W. Furofuran lignans from a callus culture of Cichorium intybus. Plant Cell Rep. 2005;24(4):246-9.

49. Pushparaj PN, Low HK, Manikandan J, Tan BK, Tan CH. Anti-diabetic effects of Cichorium intybus in streptozotocin-induced diabetic rats. J Ethnopharmacol. 2007;111(2):430-4.

50. Petrovic J, Stanojkovic A, Comic L, Curcic S. Antibacterial activity of Cichorium intybus. Fitoterapia. 2004;75(7-8):737-9.

\section{Submit your next manuscript to BioMed Central and take full advantage of:}

- Convenient online submission

- Thorough peer review

- No space constraints or color figure charges

- Immediate publication on acceptance

- Inclusion in PubMed, CAS, Scopus and Google Scholar

- Research which is freely available for redistribution

Submit your manuscript at www.biomedcentral.com/submit 